\title{
Influence of activation modes on diametral tensile strength of dual-curing resin cements
}

\section{Influência dos métodos de ativação na resistência à tração diametral de cimentos resinosos duais}

\author{
Renata Garcia Fonseca* \\ Juliana Gomes dos Santos** \\ Gelson Luis Adabo***
}

\begin{abstract}
In metallic restorations, the polymerization of dual-curing resin cements depends exclusively on chemical activation. The effect of the lack of photoactivation on the strength of these cements has been rarely studied. This study evaluated the influence of activation modes on the diametral tensile strength (DTS) of dualcuring resin cements. Base and catalyst pastes of Panavia F, Variolink II, Scotchbond Resin Cement, Rely X and Enforce were mixed and inserted into cylindrical metal moulds ( 4 × $2 \mathrm{~mm}$ ). Cements were either: 1) not exposed to light (chemical activation $=$ self-cured groups) or 2) photoactivated through mylar strips (chemical and photoactivation $=$ dual-cured groups) $(\mathrm{n}=10)$. After a $24 \mathrm{~h}$ storage in $37^{\circ} \mathrm{C}$ distilled water, specimens were subjected to compressive load in a testing machine. A self-curing resin cement (Cement-It) and a zinc phosphate cement served as controls. Comparative analyses were performed: 1) between the activation modes for each dual-curing resin cement, using Student's $t$ test; 2) among the self-cured groups of the dual-curing resin cements and the control groups, using one-way ANOVA and Tukey's test $(\alpha=0.05)$. The dual-cured groups of Scotchbond Resin Cement $(53.3 \mathrm{MPa})$, Variolink II $(48.4 \mathrm{MPa})$ and Rely X $(51.6 \mathrm{MPa})$ showed higher DTS than that of self-cured groups (44.6, 40.4 and 44.5 MPa respectively) ( $<$ 0.05). For Enforce (48.5 and 47.8 MPa) and Panavia F (44.0 and $43.3 \mathrm{MPa})$, no significant difference was found between the activation modes $(\mathrm{p}>0.05)$. The self-cured groups of all the dualcuring resin cements presented statistically the same DTS as that of Cement-It $(44.1 \mathrm{MPa})(\mathrm{p}>0.05)$, and higher DTS than that of zinc phosphate (4.2 MPa). Scotchbond Resin Cement, Variolink II and Rely X depended on photoactivation to achieve maximum DTS. In the absence of light, all the dual-curing resin cements presented higher DTS than that of zinc phosphate and statistically the same as that of Cement-It ( $>0.05)$.

DESCRIPTORS: Resin cements; Tensile strength; Dental materials.
\end{abstract}

RESUMO: Em restaurações metálicas, a polimerização dos cimentos resinosos duais depende exclusivamente da ativação química. Há poucas pesquisas sobre o efeito da supressão da fotoativação na resistência desses cimentos. Este estudo avaliou a influência de métodos de ativação na resistência à tração diametral (RTD) de cimentos resinosos duais. Pastas base e catalisadora do Panavia F, Variolink II, Scotchbond Resin Cement, Rely X e Enforce foram espatuladas e inseridas em matrizes metálicas cilindricas (4 x $2 \mathrm{~mm}$ ). Os cimentos foram: 1) não fotoativados (ativação química $=$ grupos quimicamente ativados) ou 2) fotoativados através de tira de poliéster (ativação química e foto $=$ grupos duais $)(\mathrm{n}=10)$. Após armazenamento por 24 horas em água destilada a $37^{\circ} \mathrm{C}$, os espécimes foram submetidos a forças de compressão. Um cimento resinoso de ativação química (Cement-It) e um de fosfato de zinco serviram como grupos controle. Foram feitas as seguintes comparações: 1) entre os métodos de ativação (grupos quimicamente ativados e grupos duais), para cada cimento resinoso dual, por meio do teste $t$ de Student; 2) entre os grupos quimicamente ativados dos cimentos resinosos duais e os grupos controle, empregando-se ANOVA e teste de Tukey $(\alpha=0,05)$. Os grupos duais do Scotchbond Resin Cement $(53,3 \mathrm{MPa})$, Variolink II $(48,4$ $\mathrm{MPa})$ e Rely X (51,6 MPa) tiveram maior RTD do que os seus grupos quimicamente ativados (44,6; 40,4 e 44,5 MPa, respectivamente) ( $<$ 0,05). Para o Enforce $(48,5$ e 47,8 MPa) e para o Panavia F $(44,0$ e 43,3 $\mathrm{MPa})$, não houve diferença significativa entre os métodos de ativação $(p>0,05)$. Os grupos quimicamente ativados dos cimentos duais apresentaram RTD estatisticamente semelhante à do Cement-It $(44,1 \mathrm{MPa})(\mathrm{p}>0,05)$, e maior que a do fosfato de zinco (4,2 MPa). Scotchbond Resin Cement, Variolink II e Rely X dependeram da fotoativação para alcançar valores máximos de RTD. Na ausência de luz, todos os cimentos duais apresentaram maior RTD que a do fosfato de zinco, e RTD estatisticamente semelhante à do Cement-It $(\mathrm{p}>0,05)$.

DESCRITORES: Cimentos de resina; Resistência à tração; Materiais dentários.

\footnotetext{
*PhD, Assistant Professor of Dental Materials; ***PhD, Associate Professor of Dental Materials - Department of Dental Materials and Prosthodontics, School of Dentistry of Araraquara, São Paulo State University.

** PhD Student, Department of Dentistry, School of Health Sciences, University of Brasilia.
} 
Fonseca RG, Santos JG, Adabo GL. Influence of activation modes on diametral tensile strength of dual-curing resin cements. Braz Oral Res 2005;19(4):267-71.

\section{INTRODUCTION}

Dual-curing resin cements have been used for luting not only indirect esthetic restorations, but most recently for luting metal castings such as crowns and fixed partial dentures, as an alternative to zinc phosphate and glass ionomer cements.

Some advantages of resin cements are low solubility ${ }^{24}$, adequate consistency and film thickness $^{5,21}$, superior mechanical properties ${ }^{14,22}$, optimal bonding to dental structures and restoring materials by adhesive systems ${ }^{10}$ and reduced microleakage $^{23}$.

Nevertheless, some studies have shown that dual-curing resin cements depend on photoactivation to achieve a high degree of conversion. This was investigated with four dual-curing resin cements using Fourier Transform Infrared Spectrometry (FTIR), and none of the studied cements presented similar results comparing self-cured and dual-cured groups ${ }^{18}$. Another study using six dual-curing resin cements, also analysed by FTIR, showed that, in five cements, the degree of conversion of the self-cured groups was significantly lower than that of the groups photoactivated through mylar strips or porcelain spacers ${ }^{4}$.

This lower degree of conversion demonstrated by the dual-curing resin cements which receive reduced (or no) light intensity is reflected in the hardness of the cement ${ }^{9}$.

A reduced hardness of dual-curing resin cements has been related to the partial absorption of light by the restoring esthetic materials. A study showed that the hardness of two dual-curing resin cements under composite resin inlays was $76 \%$ and $62 \%$ of the hardness values attained after direct photoactivation for the same period ${ }^{11}$. Other authors tested three dual-curing resin cements and observed higher hardness values when the cements were directly photoactivated, as compared to the groups photoactivated through porcelain spacers, and that the thickness and opacity of the porcelain produced a significant decrease in hardness of all cements ${ }^{20}$.

These findings become more critical in the cementing of metallic restorations, since the polymerization of cements is exclusively dependent on chemical activation. If a resin cement cannot adequately polymerize, both its mechanical and biological properties may be adversely affected. The complete polymerization of resin cements is essential for strength, retention and longevity of the restorations ${ }^{15}$.
Despite studies that show the influence of the activation modes on the degree of conversion and on hardness of the dual-curing resin cements, little emphasis has been given to the influence of the activation modes on other mechanical properties.

Due to the importance of this research area and the scarcity of studies that evaluate the strength of dual-curing resin cements that are not photoactivated (when resin cements are used beneath a metal casting), the purpose of the present study was to evaluate the influence of activation modes on the diametral tensile strength (DTS) of five dual-curing resin cements. The hypotheses tested were that dual activation results in a higher DTS than chemical activation and that the selfcured groups of dual-curing resin cements present statistically the same DTS as that of the self-curing resin cement, and higher DTS than that of zinc phosphate cement.

\section{MATERIALS AND METHODS}

The DTS test was conducted with five dualcuring resin cements. An exclusively self-curing resin cement and a zinc phosphate cement were included in this study and served as controls. All the cements examined are listed in Table 1.

Cylindrical specimens with $4.0 \mathrm{~mm}$ in diameter and $2.0 \mathrm{~mm}$ in height were built using stainless steel moulds. For all resin cements, equal amounts $(0.10 \mathrm{~g})$ of the base and catalyst pastes were proportioned. In the case of the zinc phosphate cement, where the manufacturer supplies $1.4 \mathrm{~g}$ of powder per $0.4 \mathrm{ml}$ of liquid, a conversion of liquid volume to mass was performed, resulting in a proportion of $1.4 \mathrm{~g}$ of powder to $1.54 \mathrm{~g}$ of liquid.

The mould was placed on a mylar strip (Polidental Indústria e Comércio Ltda., São Paulo, SP, Brazil) over a glass slab. Zinc phosphate cement was mixed within 90 seconds with a spatula and following an incremental technique. The resin cements were mixed for 15 seconds according to manufacturers' directions. The cements were inserted into moulds with a slight excess of material. Mylar strip, glass slab, a metallic support with an opening to allow photoactivation and a $0.5 \mathrm{~kg}$ weight were positioned on top of the resin cements to permit overflow of the excess material. For the dual-curing resin cements such procedures were made inside an X-ray developing chamber (Odontologic Indústria e Comércio Ltda., São Paulo, SP, Brazil) to avoid the exposure of the specimens to daylight. 
Fonseca RG, Santos JG, Adabo GL. Influence of activation modes on diametral tensile strength of dual-curing resin cements. Braz Oral Res 2005;19(4):267-71.

The specimens were subjected to one of the following treatments:

1) not exposed to light: the specimens remained inside the X-ray developing chamber for 40 minutes and then were detached from the mould and stored in lightproof containers with distilled water at $37^{\circ} \mathrm{C}$ for 24 hours (self-cured groups).

2) photoactivated: the specimens were photoactivated on the upper and lower surfaces for 60 seconds, using a halogen light source photoactivation unit (Curing Light 2500, 3M Co., St. Paul, MN, USA) with $510 \mathrm{~mW} / \mathrm{cm}^{2}$ intensity and then detached from the mould. Following 38 minutes of final photoactivation, the specimens were stored in the same way as described above (dual-cured groups).

The cements of the control groups received the same treatment as the self-cured groups, i.e., the specimens were detached from the mould after a

TABLE 1 - Filler content and type of monomer of the cements used in this study.

\begin{tabular}{|c|c|c|}
\hline $\begin{array}{c}\text { Cements } \\
\text { (Manufacturers) }\end{array}$ & Monomers* & $\begin{array}{c}\text { Filler } \\
\text { content* }(\% \\
\text { weight) }\end{array}$ \\
\hline $\begin{array}{l}\text { Zinc Phosphate } \\
\text { (S.S.White, Rio de } \\
\text { Janeiro, RJ, Brazil) }\end{array}$ & - & - \\
\hline $\begin{array}{l}\text { Variolink II (DCRC) } \\
\text { (Vivadent, Amherst, } \\
\text { NY, USA) }\end{array}$ & $\begin{array}{l}\text { Bis-GMA, } \\
\text { UEDMA, } \\
\text { TEGDMA }\end{array}$ & 73.4 \\
\hline $\begin{array}{l}\text { Scotchbond Resin } \\
\text { Cement (DCRC) } \\
\text { (3M ESPE, St. Paul, } \\
\text { MN, USA) }\end{array}$ & $\begin{array}{l}\text { Bis-GMA, } \\
\text { TEGDMA }\end{array}$ & 78.5 \\
\hline $\begin{array}{l}\text { Rely X (DCRC) } \\
\text { (3M ESPE, St. Paul, } \\
\text { MN, USA) }\end{array}$ & $\begin{array}{l}\text { Bis-GMA, } \\
\text { TEGDMA }\end{array}$ & 67.5 \\
\hline $\begin{array}{l}\text { Enforce (DCRC) } \\
\text { (Dentsply, } \\
\text { Petrópolis, RJ, } \\
\text { Brazil) }\end{array}$ & $\begin{array}{l}\text { Bis-GMA, } \\
\text { BHT, EDAB, } \\
\text { TEGDMA }\end{array}$ & 66.0 \\
\hline $\begin{array}{l}\text { Panavia F (DCRC) } \\
\text { (Kuraray, Umeda, } \\
\text { Osaka, Japan) }\end{array}$ & $\begin{array}{l}\text { Bisphenol A } \\
\text { polyethoxy } \\
\text { dimethacrylate, } \\
\text { MDP }\end{array}$ & 78.0 \\
\hline $\begin{array}{l}\text { Cement-It (SCRC) } \\
\text { (Jeneric Pentron, } \\
\text { Wallingford, CT, } \\
\text { USA) }\end{array}$ & $\begin{array}{l}\text { Bis-GMA, } \\
\text { UDMA, } \\
\text { HDDMA }\end{array}$ & 68.0 \\
\hline
\end{tabular}

$\mathrm{DCRC}=$ dual-curing resin cement. $\mathrm{SCRC}=$ self-curing resin cement. *Information provided by the manufacturers. 40-minute interval and stored in the same way as described previously.

Ten specimens were prepared for each combination of activation mode and resin cement.

Specimens were subjected to compressive load in a testing machine (Material Test System 810, Eden Prairie, MN, USA), at a crosshead speed of $0.5 \mathrm{~mm} / \mathrm{min}$ until fracture. Maximum DTS values were recorded in MPa and means were determined for each group. Statistical analyses were performed with computer software (GMC 8.1 statistical package; University of São Paulo, Ribeirão Preto Dental School, Brazil).

The following comparative analyses were performed:

1) between the activation modes (self-cured and dual-cured groups) separately for each dualcuring resin cement, using unpaired Student's $t$ test;

2) among the self-cured groups of the dual-curing resin cements and the control groups, using one-way analysis of variance and Tukey's test $(\alpha=0.05)$.

\section{RESULTS}

Table 2 demonstrates the mean values of DTS of the self- and dual-cured groups of the examined dual-curing resin cements. The dual-cured groups of Scotchbond Resin Cement, Variolink II and Rely $\mathrm{X}$ cements showed significantly higher DTS (MPa) than those self-cured. For Enforce and Panavia F, no significant difference was found between the activation modes.

The strength means of the self-cured groups of the dual-curing resin cements, the means of the control groups and the statistical differences highlighted by Tukey's test are presented in Table 3 . The self-cured groups of all the dual-curing resin cements presented similar strengths to each other

TABLE 2 - Mean DTS values (MPa) and statistical results.

\begin{tabular}{l|c|cc|c}
\hline \hline & self-cured & \multicolumn{2}{|c|}{ dual-cured } & $\mathrm{p}$ \\
\hline $\begin{array}{l}\text { Scotchbond } \\
\text { Resin Cement }\end{array}$ & $44.6(6.2)$ & $53.3(10.5)$ & $0.0372^{*}$ \\
\hline Panavia F & $43.3(3.8)$ & 44.0 & $(4.8)$ & 0.7250 \\
\hline Variolink II & $40.4(6.8)$ & 48.4 & $(8.0)$ & $0.0272^{*}$ \\
\hline Rely X & $44.5(7.0)$ & 51.6 & $(5.9)$ & $0.0232^{*}$ \\
\hline Enforce & $47.8(5.4)$ & 48.5 & $(8.3)$ & 0.8044 \\
\hline \hline
\end{tabular}

*Statistically significant difference $(\mathrm{p}<0.05)$. Standard deviations are shown in parentheses. 
Fonseca RG, Santos JG, Adabo GL. Influence of activation modes on diametral tensile strength of dual-curing resin cements. Braz Oral Res 2005;19(4):267-71.

TABLE 3 - Mean DTS values $(\mathrm{MPa})$ and statistical grouping of the self-cured and control groups.

\begin{tabular}{l|c|c}
\hline \multicolumn{1}{c|}{$\begin{array}{c}\text { Experimental } \\
\text { Materials }\end{array}$} & Mean DTS & $\begin{array}{c}\text { Statistical } \\
\text { Grouping }\end{array}$ \\
\hline Enforce & $47.8(5.4)$ & $\mathrm{A}$ \\
\hline $\begin{array}{l}\text { Scotchbond } \\
\text { Resin Cement }\end{array}$ & $44.6(6.2)$ & $\mathrm{A}$ \\
\hline Rely X & $44.5(7.0)$ & $\mathrm{A}$ \\
\hline Panavia F & $43.3(3.8)$ & $\mathrm{A}$ \\
\hline Cement-It & $44.1(6.3)$ & $\mathrm{A}$ \\
\hline Variolink II & $40.4(6.8)$ & $\mathrm{A}$ \\
\hline Zinc Phosphate & $4.2(0.5)$ & $\mathrm{B}$ \\
\hline \hline
\end{tabular}

Standard deviations are shown in parentheses.

and to that of Cement-It, and higher strengths than that of zinc phosphate.

\section{DISCUSSION}

The statistically significant difference observed between the self- and dual-cured groups of the Scotchbond Resin Cement, Variolink II and Rely X resin cements demonstrates that these materials depend on photoactivation to achieve maximum diametral tensile strength, in contrast to the Enforce and Panavia F cements.

In terms of percentage, the self-cured groups of Scotchbond Resin Cement, Variolink II and Rely $\mathrm{X}$ cements demonstrated $83.7 \%, 83.5 \%$ and $86.2 \%$ of the diametral tensile strength values of the respective dual-cured groups, while the self-cured groups of Enforce and Panavia F presented 98.5\% and $98.4 \%$, respectively.

Even though there are no studies reporting diametral tensile strength of dual-curing resin cements in relation to activation mode, other mechanical properties were investigated and conform well with the present findings. After 24 hours of storage, the Enforce cement had similar hardness and flexural strength if it had been self- or dualcured, while Variolink II and Rely X depended upon photoactivation to achieve higher hardness and flexural strength values ${ }^{3}$. In another study, Variolink II cement also showed statistically significant difference between flexural strength values of self- and dual-cured groups ${ }^{12}$. Similar results were reported for the Rely X and Calibra cements ${ }^{2}$. For Scotchbond Resin Cement, the heat from the photopolymerization reaction is greater than that produced by chemical polymerization ${ }^{13}$.
This difference in behavior, in relation to activation modes, observed among the different brands of dual-curing resin cements has also been reported by other researchers and may be explained by the marked differences in materials formulation, such as quantity ${ }^{7,8,11}$ and efficacy ${ }^{16}$ of the photo and chemical components of the setting mechanisms, which together with the quantity and quality of the polymeric and inorganic phases, have a direct influence on the mechanical and biological properties of resin cements ${ }^{2,8,17}$. Some products are so dependent on photoactivation that they cannot be recommended in situations in which light transmission is not effective ${ }^{16}$. This is a fact of great clinical relevance, particularly in the cementing of metallic restorations, where the cement depends exclusively on chemical activation. In such cases, an adequate cement is one that, even under no light conditions, is capable of attaining, even in the initial moments after cementing, a sufficient strength to resist the masticatory efforts, thereby reducing the risk of dislodgment of restorations. Therefore, further investigation should be performed in order to analyze the same property in shorter periods of time.

As to the comparative analyses of the selfcured groups of the dual-curing cements and the control groups, the low diametral tensile strength exhibited by the zinc phosphate cement was also reported in other studies ${ }^{14,19,22}$ and can be explained by the properties of this material, which makes it brittle and consequently less resistant to tensile stresses.

In addition, it should be observed that even though the Scotchbond Resin Cement, Variolink II and Rely X cements presented statistical differences between the activation modes, these materials, when activated by chemical means alone, attained statistically similar strength values to those exhibited by Panavia F and Enforce, when subjected to the same treatment, and to that of the self-curing resin cement, Cement-It ( $p>0.05)$.

The degree of conversion is not the sole factor responsible for the mechanical properties of composites. Filler type and content $t^{6}$ and monomer type ${ }^{1}$ were found to be determinant factors of diametral tensile strength. As reported in some studies ${ }^{3,4,12}$, Variolink II does not present a substantial curing potential in the absence of light. However, this cement presented a statistically similar strength to that of the Enforce cement, which depends little on photoactivation. Besides the high filler content compared to that of Enforce, another possible explanation for the behaviour of Variolink 
Fonseca RG, Santos JG, Adabo GL. Influence of activation modes on diametral tensile strength of dual-curing resin cements. Braz Oral Res 2005;19(4):267-71.

II would be the presence of UEDMA in its composition. The replacement of Bis-GMA or TEGDMA by UEDMA results in an increase in diametral tensile strength $^{1}$. The monomer UEDMA is more flexible than Bis-GMA because of the urethane linkages, and it presents lower viscosity, which facilitates the migration of free radicals, increasing the degree of crosslinking.

Despite the fact that the resin cements presented higher diametral tensile strength values than zinc phosphate cement, additional studies which evaluate microleakage, susceptibility to degradation and other mechanical properties should be carried out to obtain better parameters for the utilization of these materials in the cementing of metallic restorations.

\section{REFERENCES}

1. Asmussen E, Peutzfeldt A. Influence of UEDMA, BisGMA and TEGDMA on selected mechanical properties of experimental resin composites. Dent Mater 1998;14(1):51-6.

2. Attar N, Tam LE, McComb D. Mechanical and physical properties of contemporary dental luting agents. J Prosthet Dent 2003;89(2):127-34.

3. Braga RR, Cesar PF, Gonzaga CC, Bianchi J. Mechanical properties of resin cements with different activation modes. J Oral Rehabil 2002;29(3):257-62.

4. Caughman WF, Chan DCN, Rueggeberg FA. Curing potential of dual-polymerizable resin cements in simulated clinical situations. J Prosthet Dent 2001;85(5):479-84.

5. Christensen GJ. Seating nonmetal crowns or fixed partial dentures with resin cement. J Am Dent Assoc 1998;129(2):239-41.

6. Chung KH, Greener EH. Correlation between degree of conversion, filler concentration and mechanical properties of posterior composite resins. J Oral Rehabil 1990;17(5):48794.

7. El-Badrawy WA, El-Mowafy OM. Chemical versus dual curing of resin inlay cements. J Prosthet Dent 1995;73(6):515-24.

8. El-Mowafy OM, Rubo MH, El-Badrawy WA. Hardening of new resin cements cured through a ceramic inlay. Oper Dent 1999;24(1):38-44.

9. Ferracane JL. Correlation between hardness and degree of conversion during the setting reaction of unfilled dental restorative resins. Dent Mater 1985;1(1):11-4.

10. Gorodovsky S, Zidan O. Retentive strength, disintegration, and marginal quality of luting cements. J Prosthet Dent 1992;68(2):269-74.

11. Hasegawa EA, Boyer DB, Chan DCN. Hardening of dual-cured cements under composite resin inlays. J Prosthet Dent 1991;66(2):187-92.

12. Hofmann N, Papsthart G, Hugo B, Klaiber B. Comparison of photo-activation versus chemical or dualcuring of resin-based luting cements regarding flexural strength, modulus and surface hardness. J Oral Rehabil 2001;28(2):1022-8.

13. Lee IB, Um CM. Thermal analysis on the cure speed of dual cured resin cements under porcelain inlays. J Oral Rehabil 2001;28(2):186-97.

\section{CONCLUSIONS}

Based on the results of this in vitro study, it may be concluded that Scotchbond Resin Cement, Variolink II and Rely X resin cements demonstrated significant decreases in diametral tensile strength in the absence of photoactivation, while Enforce and Panavia F presented similar diametral tensile strengths in the two activation modes.

All dual-curing resin cements, when chemically activated, had higher diametral tensile strength values than zinc phosphate cement and showed similar diametral tensile strengths between them, which were similar to that of the self-curing resin cement, Cement-It.

14. Li ZC, White SN. Mechanical properties of dental luting cements. J Prosthet Dent 1999;81(5):597-609.

15. McComb D. Adhesive luting cements - Classes, criteria and usage. Compend Contin Educ Dent 1996;17(8):75973.

16. Peutzfeldt A. Dual-cure resin cements: in vitro wear and effect of quantity of remaining double bonds, filler volume, and light curing. Acta Odontol Scand 1995;53(1):2934.

17. Rosenstiel SF, Land MF, Crispin BJ. Dental luting agents: A review of the current literature. J Prosthet Dent 1998;80(3):280-301.

18. Rueggeberg FA, Caughman WF. The influence of light exposure on polymerization of dual-cure resin cements. Oper Dent 1993;18(2):48-55.

19. Smith DC. Dental cements. Current status and future prospects. Dent Clin North Am 1983;6(4):763-92.

20. Uctasli S, Hasanreisoglu U, Wilson HJ. The attenuation of radiation by porcelain and its effect on polymerization of resin cements. J Oral Rehabil 1994;21(6):565-75.

21. Van Meerbeek B, Inokoshi S, Davidson CL, De Gee AL, Lambrechts P, Braem M, et al. Dual curing luting composites. Part II: clinically related properties. J Oral Rehabil 1994;21(1):57-66.

22. White SN, Yu Z. Compressive and diametral tensile strengths of current adhesive luting agents. J Prosthet Dent 1993;69(6):568-72.

23. White SN, Yu Z, Tom JFMD, Sangsurasak S. In vivo microleakage of luting cements for cast crowns. J Prosthet Dent 1994;71(4):333-8.

24. Yoshida K, Tanagawa M, Atsuta M. In vitro solubility of three types of resin and conventional luting cements. J Oral Rehabil 1998;25(4):285-91.

Received for publication on Apr 06, 2005

Sent for alterations on Jun 03, 2005 Accepted for publication on Sep 21, 2005 